\title{
Effects of salinity and nutrient conditions on growth and haemolytic activity of Fibrocapsa japonica (Raphidophyceae)
}

\author{
M. Karin de Boer ${ }^{1, *}$, Monika R. Tyl ${ }^{1}$, Engel G. Vrieling ${ }^{2}$, Marion van Rijssel ${ }^{1}$ \\ ${ }^{1}$ Department of Marine Biology, Centre for Ecological and Evolutionary Studies, and ${ }^{2}$ Groningen Biomolecular Sciences and \\ Biotechnology Institute, University of Groningen, Biological Centre, PO Box 14, 9750 AA Haren, The Netherlands
}

\begin{abstract}
The influence of salinity and a number of nitrogen $(\mathrm{N})$ and phosphorus $(\mathrm{P})$ levels on growth and haemolytic activity of the harmful algal bloom (HAB) species Fibrocapsa japonica were studied simultaneously. The F. japonica strain studied had a euryhaline growth profile with an optimum growth rate at 26 psu. Measurements of the minimum cell quota of $\mathrm{N}$ and $\mathrm{P}$ revealed an optimum N:P ratio of 24.5 and a relatively high requirement of nutrients $\left(q_{0} \mathrm{~N}=7.1 \mathrm{pmol} \mathrm{cell}^{-1} ; q_{0} \mathrm{P}=\right.$ $0.29 \mathrm{pmol} \mathrm{cell}^{-1}$ ). These characteristics fit the habitat of this species, among which is the P-controlled eutrophied Dutch coastal waters. Salinity had a significant effect on the growth rate of $F$. japonica and on its haemolytic activity, even on the basis of equal cell volume. The highest haemolytic activity was found at $16 \mathrm{psu}$, the lowest salinity condition tested. The $\mathrm{EC}_{50}$ values that were expressed on a per cell basis revealed that $F$. japonica had a high haemolytic activity when compared with other HAB species. Under $\mathrm{N}$ limitation, cells of $F$. japonica were less haemolytic than cells not limited for $\mathrm{N}$, but this could be caused by a slight decrease in cell volume only. Remarkably, cells not limited for N appeared to form aggregates, which in combination with the elevated levels of haemolytic compounds per cell may result in obstruction of gills, causing fish kills during F. japonica blooms. So, despite the absence of brevetoxin in our strain of $F$. japonica, this strain may be lethal to fish due to its haemolytic activity.
\end{abstract}

KEY WORDS: Cell quota $\cdot \mathrm{N}:$ P ratio $\cdot$ Brevetoxins $\cdot$ Toxicity $\cdot$ Harmful algal blooms $\cdot$ Phytoplankton Resale or republication not permitted without written consent of the publisher

\section{INTRODUCTION}

Proposed explanations for the global increase in harmful algal blooms (HABs) are the stimulation of plankton blooms by eutrophication and/or unusual climatological conditions (Hallegraeff et al. 2003). There is a considerable concern (Ryther \& Dunstan 1971, Officer \& Ryther 1980, Smayda 1990) that coastal waters such as the North Sea with high anthropogenic nitrogen input may favour blooms of nuisance species. The altered nutrient ratios are beneficial for flagellates that replace the normal spring and autumn blooms of siliceous diatoms (Colijn \& Cadée 2003, Hallegraeff et al. 2003). In the North Sea, along the Dutch and German coast, an increase in phytoplankton abundance and shifts in species composition were observed over the past decades, which have been attributed to anthropogenically altered nutrient conditions (Radach \& Berg 1986, Riegman et al. 1992, Cadée \& Hegeman 1993, Philippart et al. 2000, Cadée \& Hegeman 2002). Since the 1990s, one of the frequently observed HAB species in these coastal waters is the marine raphidophyte Fibrocapsa japonica Toriumi and Takano (Vrieling et al. 1995, Rademaker et al. 1998). Possibly, this species also thrives due to changing environmental conditions.

Fibrocapsa japonica and other marine raphidophyte species, Chattonella spp., Heterosigma akashiwo and Olistodiscus luteus, have been documented to be ichthyotoxic (Landsberg 2002 and references therein). $F$. japonica has caused massive fish mortality events in the Seto Inland Sea of Japan (Iwasaki 1971, Okaichi 
1972, 1989, Toriumi \& Takano 1973); since 1990 ichthyotoxicity of $F$. japonica has been reported from the German coast and the Mediterranean Sea (European Commission 2003). The fish kills caused by F. japonica have been ascribed to the production of brevetoxins (Khan et al. 1996, Bridgers et al. 2004), reactive oxygen species (ROS; Oda et al. 1997), haemolytic compounds (Fu et al. 2004a,b), mucocyst ejection (de Boer et al. 2004b), and possibly combinations of these. Raphidophyte species are not always toxic to fish, as was shown for $H$. akashiwo and Chattonella spp. (Ishimatsu et al. 1996, Twiner \& Trick 2000). Therefore, it is likely that different strains produce different toxic compounds or sometimes no toxins at all; this may be the case for F. japonica as well. The production of toxic compounds by raphidophytes could also be affected by environmental conditions such as light (Ono et al. 2000, Khan et al. 2001, Marshall et al. 2002), temperature (Twiner \& Trick 2000, Khan et al. 2001), salinity (Haque \& Onoue 2002a,b) and the presence of bacteria (Carrasquero-Verde 1999). For other HAB algae, it is known that algal species react differently to altered nutrient conditions with respect to toxin production (Granéli et al. 1998).

So far, toxin production by raphidophytes has not been studied in relation to nutrient conditions. In this study, we concentrated on the role of salinity and nutrient conditions both on growth performance and on the production of toxins. We used a European strain of Fibrocapsa japonica, which is known to give results in toxicity tests with bioassays using the brine shrimp Artemia salina or luminescent bacteria (Fu et al. 2004b) and that contains haemolytic compounds identified as polyunsaturated fatty acids (PUFAs; Fu et al. 2004a,b). This study is part of a larger project on the competitive advantage of $F$. japonica necessary for establishment in new areas. Therefore, we investigated the physiological niche of this species, which is defined by several aspects of growth performance. We studied growth in relation to temperature (de Boer et al. 2004b) and life cycle phenomena related to survival (de Boer et al. 2004a).

\section{MATERIALS AND METHODS}

Culture conditions. The western European Fibrocapsa japonica strain CCRuG-Cl3 (Culture Collection University of Groningen, The Netherlands) was used for this study. Strain CCRuG-Cl3 is a clonal F. japonica culture established in 1997 from a culture of a monospecific bloom that occurred in 1995 in Büsum harbour, Germany (U. Tillmann pers. comm.). This non-axenic strain was grown in batch culture using autoclaved natural seawater (Doggersbank, North Sea) adjusted to a salinity of 25 psu with Milli-Q water and enriched with f/2 minus Si (Guillard 1975). The cultures were routinely maintained at $17 \pm 1^{\circ} \mathrm{C}$ under long-day (16:8 h light: dark, L:D) conditions and a photon flux density of $50 \pm$ $5 \mu \mathrm{mol}$ photons $\mathrm{m}^{-2} \mathrm{~s}^{-1}$ (provided by fluorescent tubes L36W/19 light, Osram). The irradiance was measured with a Li-Cor quantum meter equipped with a cosine collector. A stock culture was diluted every second day with new f/2 medium, keeping the cells in an exponential growth phase for at least 4 generations. The last generation was used as inoculum for the experiments. In pilot experiments, a direct shift from 25 psu to 15 or 35 psu did not show cell stress, which is observed as the absence of mucus ejection, nor did it induce a lag phase.

Experimental set-up. The Fibrocapsa japonica strain was cultured at different salinities $(16,21,26,31$, $36 \mathrm{psu}$ ). The initial N:P ratios (4 nutrient treatments) were varied too; abbreviations for nitrogen $(\mathrm{N})$ and phosphorus (P) are: $\mathrm{N}_{\mathrm{H}}=\operatorname{high}[\mathrm{N}] ; \mathrm{N}_{\mathrm{L}}=$ low $[\mathrm{N}] ; \mathrm{P}_{\mathrm{H}}=$ high $[\mathrm{P}]$; and $\mathrm{P}_{\mathrm{L}}=$ low $[\mathrm{P}]$ (Table 1 ). All possible combinations $(n=20)$ between salinity $(n=5)$ and nutrient treatment $(n=4)$ were tested.

When the experiment was started, the stock culture was not nutrient limited, the cells were in exponential phase and all the cells had the same nutrient history. The inoculum used was small (50 into $750 \mathrm{ml}$ ) to minimise influence on the initial salinity and nutrient concentration of the fresh medium. The experiment was done in 2011 Erlenmeyer flasks with different salinity/nutrient treatments, and each flask had an initial cell density of $800 \pm 200$ cells $\mathrm{ml}^{-1}$.

Every second day, each culture was sampled for cell density, $\mathrm{N}$ and $\mathrm{P}$ analysis, erythrocyte lysis assay and brevetoxin analysis. Before sampling, each culture was checked by visual inspection for motile and non-motile cells and for cell aggregation, and cultures were gently swirled and placed back randomly after sampling. Salinity and $\mathrm{pH}$ in each flask were checked regularly, but no changes were recorded during the experiment.

Cell density measurements. Phytoplankton samples (5 ml) were kept in $20 \mathrm{ml}$ brown glass flasks and preserved with $75 \mu$ acid Lugol's solution (Veldhuis et al.

Table 1. The 4 nutrient conditions at the start of the experiment. $\mathrm{N}_{\mathrm{H}}=$ high $[\mathrm{N}] ; \mathrm{N}_{\mathrm{L}}=$ low $[\mathrm{N}] ; \mathrm{P}_{\mathrm{H}}=$ high $[\mathrm{P}]$; and $\mathrm{P}_{\mathrm{L}}=$ low $[\mathrm{P}]$. Each nutrient treatment was carried out for all 5 salinities $(16,21,26,31,36 \mathrm{psu})$. Nutrient conditions with initial N:P ratio of 24 were the enriched seawater media $f / 20$ and $f / 2$ (Guillard 1975)

\begin{tabular}{|lccc|}
\hline Initial N:P ratio & $\mu \mathrm{M} \mathrm{N}$ & $\mu \mathrm{M} P$ & Abbreviation \\
\hline 2.4 & 88.3 & 36.3 & $\mathrm{~N}_{\mathrm{L}} \mathrm{P}_{\mathrm{H}}$ \\
$24(\mathrm{f} / 20)$ & 88.3 & 3.63 & $\mathrm{~N}_{\mathrm{L}} \mathrm{P}_{\mathrm{L}}$ \\
$24(\mathrm{f} / 2)$ & 883 & 36.3 & $\mathrm{~N}_{\mathrm{H}} \mathrm{P}_{\mathrm{H}}$ \\
240 & 883 & 3.63 & $\mathrm{~N}_{\mathrm{H}} \mathrm{P}_{\mathrm{L}}$ \\
\hline
\end{tabular}


1986). The samples were stored in the dark at $4^{\circ} \mathrm{C}$ and counted within $4 \mathrm{~d}$ after sampling in a Sedgwick Rafter counting chamber under a Zeiss microscope using 125 magnification ( $\mathrm{n}=6$; each count with a minimum of 100 cells and all counts of 1 sample had a CV $<0.25$, where $\mathrm{CV}=$ standard deviation of all counts divided by average of all counts). Growth rates $(\mu)$ were calculated from a curve fit on at least 4 data points in the exponential phase of growth using the following equation:

$$
N_{t}=N_{0} \cdot \mathrm{e}^{(\mu t)}
$$

where $N_{t}$ and $N_{0}$ are cell concentrations at time $t$ and 0 (in days).

Nutrient measurements. A phytoplankton sample of $20 \mathrm{ml}$ was centrifuged for $15 \mathrm{~min}$ at $1360 \times g$. The cellfree supernatant was used for the analysis of phosphorus (P) and nitrogen (N) concentration of the medium. $\mathrm{P}$ concentration was determined colorimetrically at 882 nm (Pye Unicam PU 8600 UV/VIS spectrophotometer, Philips) in $4 \mathrm{~cm}$ quartz cuvets according to Harrison (1988). N concentration $\left[\mathrm{NO}_{\mathrm{x}}\right]$ was determined with the Total Nitric Oxide Assay kit (DE 1600, R \& D systems). The analysis was carried out in 96 well plates (Greiner, PS microplate, F bottom) and absorbance was measured with a Wallac 1420 Multilable Counter Victor ${ }^{\mathrm{TM}}$ at $545 \mathrm{~nm}$.

The cell quota $(q)$ of $\mathrm{N}$ or $\mathrm{P}\left(\mathrm{pmol} \mathrm{cell}{ }^{-1}\right)$ for each nutrient treatment was determined by the differences of the nutrient concentration $(S)$ of the medium between time $t$ and 0 divided by the difference in cell density $(N)$ between time $t$ and 0 , using the following equation:

$$
q=\left(S_{0}-S_{t}\right) /\left(N_{t}-N_{0}\right)
$$

Extraction of toxic substances. The Fibrocapsa japonica cells of each phytoplankton sample were harvested by filtration of $10 \mathrm{ml}$ culture on GF/F, $25 \mathrm{~mm} \varnothing$, Whatman filters, and the filters were immediately stored at $-80^{\circ} \mathrm{C}$. The filters were cut into pieces and extracted with $2 \mathrm{ml} \mathrm{MeOH}$ (HPLC grade). After $2 \mathrm{~h}$ sonification on ice, the filter material was centrifuged to the bottom of the vial. The extract was harvested and stored at $-18^{\circ} \mathrm{C}$ until analysis. For toxicity analysis, the $\mathrm{MeOH}$ was evaporated in a vacuum centrifuge (DNA 110, Speed Vac ${ }^{\circledR}$, Savant) at room temperature and the algal extract was re-dissolved in $1 \mathrm{ml}$ assay buffer (ELA buffer; Eschbach et al. 2001) and partly used for the erythrocyte lysis assay (ELA). The remaining part of the extracts was used for brevetoxin analysis. As a control, f/2 medium was filtered over a GF/F, $25 \mathrm{~mm} \varnothing$ filter. The control was treated identically as the filtered culture samples and was tested for haemolytic activity and brevetoxins ( $\mathrm{n}=4$ for both toxicity test); none were positive.

Erythrocyte lysis assay. An ELA was carried out to test the haemolytic activity of the samples. The method was essentially from Eschbach et al. (2001), but was adjusted to rat erythrocytes instead of using fish erythrocytes. From a rat that was chosen randomly, a $0.25 \mathrm{ml}$ blood sample was taken and immediately diluted in $20 \mathrm{ml}$ ELA buffer. The erythrocytes were used for the ELA within an hour after blood sampling. A dilution series was made in duplicate for each extract. The ELA test started when the washed erythrocyte solution with proper density was added to the samples. After $24 \mathrm{~h}$ incubation at $16^{\circ} \mathrm{C}$, the absorption of the supernatant was measured at $405 \mathrm{~nm}$ using the Wallac 1420 Multilable Counter Victor ${ }^{\mathrm{TM}}$.

The cell densities of Fibrocapsa japonica from the dilution series were plotted against the \% erythrocyte lysis and were fitted with a sigmoidal equation. From this exercise, the $\mathrm{EC}_{50}$ was calculated for each treatment as the concentration of $F$. japonica (cells $\mathrm{ml}^{-1}$ ) necessary for $50 \%$ lysis of the erythrocytes. Saponin (Sigma) was used as a reference.

Khan et al. (1996) suggested that the brevetoxin PbTx 2 is one of the main components of the neurotoxin fraction produced by Fibrocapsa japonica. Therefore, PbTx 2 (Calbiochem) was used as brevetoxin control. Dilution series of PbTx 2 were made up to a maximum concentration of $10 \mu \mathrm{g} \mathrm{ml}^{-1}$, and these were tested for haemolytic activity as well.

Competitive ELISA for brevetoxin analysis. Filter extracts in ELA buffer were used for the brevetoxin analysis using competitive ELISA methodology. The brevetoxin method developed by J. Naar and coworkers, is a multistep competitive biotin-strepavidin coupled immunoperoxidase technique described previously (Bourdelais et al. 2002, Naar et al. 2002). This analysis of samples was performed in collaboration with J. Naar at the Centre for Marine Science (University of North Carolina at Wilmington, USA). Before brevetoxin analysis of the samples the ELA buffer was tested for interference with either brevetoxin or one of the antibodies used in the ELISA. No interference was found. To make sure that the amount of cells tested was sufficient regarding the detection limits of $\pm 1.3 \mathrm{ng} \mathrm{ml}^{-1}$, we used 1 to $2 \times 10^{5}$ cells $\mathrm{ml}^{-1}$, which is 3 to 6 times the concentration used by Bridgers et al. (2004), who used $3 \times 10^{4}$ cells ml ${ }^{-1}$ of Fibrocapsa japonica cells and detected brevetoxins.

Statistical analysis. Differences in $\mathrm{N}$ or $\mathrm{P}$ cell quota were tested with a single factor ANOVA using the statistics tools of Excel 97 at a significance level $p<0.05$. Growth rates and haemolytic activity in relation to salinity, nutrient treatment and growth phase were analysed by regression models using SPSS 11.0. Models were constructed using a stepwise procedure including both linear and quadratic terms for the independent variable (salinity) to investigate possible non-linearity. Nutrient treatment and growth phase were compared using 'dummy' variables. Tests for inclusion of variables 
were based on F-distribution of the change in deviance per degree of freedom (when the variable was dropped from the full model) divided by the deviance per degree freedom of the full model (Crawley 1993).

\section{RESULTS}

\section{Growth at different environmental conditions}

At each salinity a similar picture for the nutrient treatments was observed. Fig. 1 shows the typical curves for these observations at a salinity of 26 psu. In the expo-
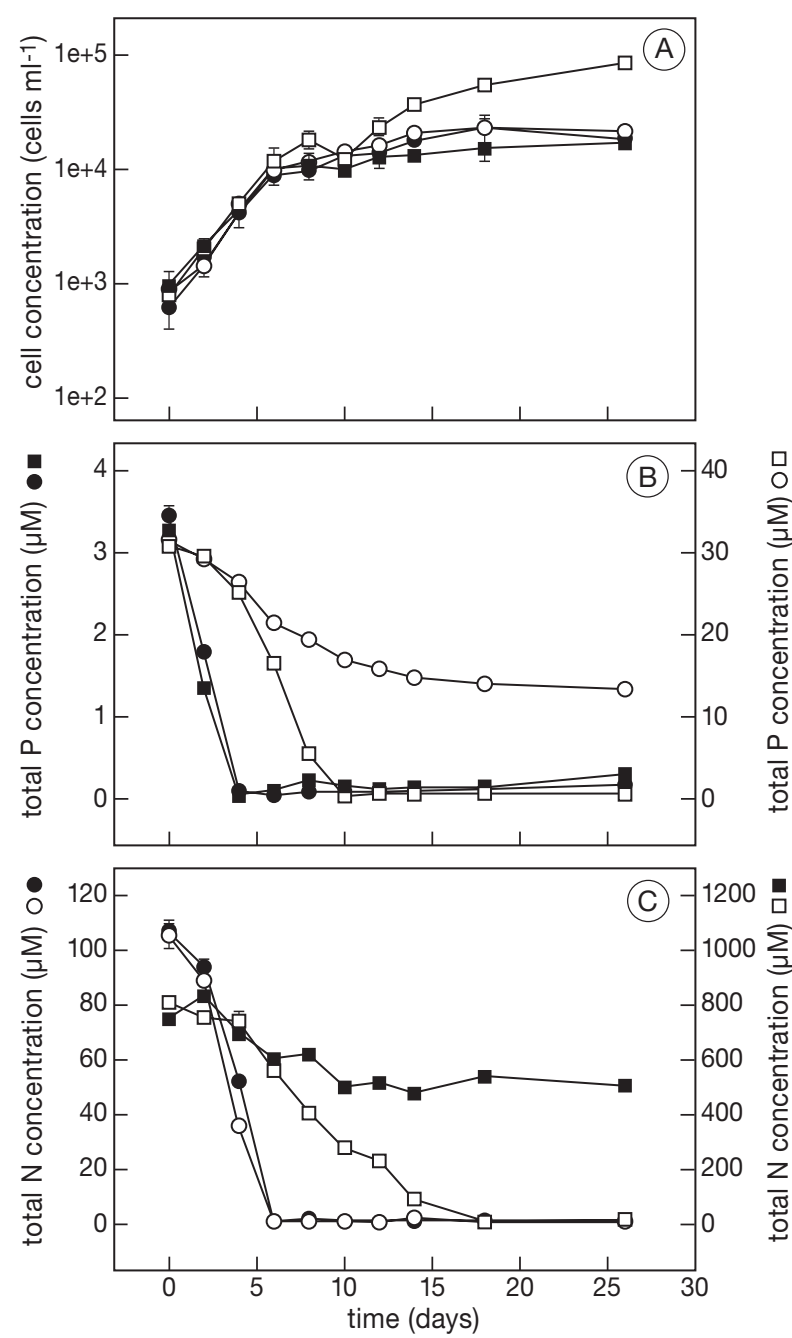

Fig. 1. Fibrocapsa japonica. Typical curves for (A) growth, (B) phosphorus and (C) nitrogen uptake in the cultures at 26 psu for all treatments. Symbols refer to the distinct applied nutrient treatments; they are also used to show the accompanying $y$-axes; $=\mathrm{N}_{\mathrm{L}} \mathrm{P}_{\mathrm{L}}$ - $=\mathrm{N}_{\mathrm{H}} \mathrm{P}_{\mathrm{L}} \mathrm{O}=\mathrm{N}_{\mathrm{L}} \mathrm{P}_{\mathrm{H}} ; \mathrm{\square}=\mathrm{N}_{\mathrm{H}} \mathrm{P}_{\mathrm{H}}(\mathrm{N}=$ nitrogen; $\mathrm{P}=$ phosphorus; $\mathrm{L}=$ low concentration; $\mathrm{H}=$ high concentration) nential growth phase (Fig. 1A) all low P treatments became $\mathrm{P}$ depleted (depleted at $[\mathrm{P}]<0.7 \mu \mathrm{M}$ ) at Day 4 (Fig. 1B). N depletion (depleted at $[\mathrm{N}]<5 \mu \mathrm{M}$ ) for the low $\mathrm{N}$ treatments was reached at Day 6 (Fig. 1C).

In the $\mathrm{f} / 2$ treatment of each salinity, $\mathrm{N}_{\mathrm{H}} \mathrm{P}_{\mathrm{H}}, \mathrm{P}$ depletion was observed later (from Days 10 to 18). At Days 18 to 26 , the $[\mathrm{N}]$ in the $\mathrm{N}_{\mathrm{H}} \mathrm{P}_{\mathrm{H}}$ treatment levelled off at concentrations between 7 and $54 \mu \mathrm{M}$, for the whole salinity range. In the treatments $\mathrm{N}_{\mathrm{L}} \mathrm{P}_{\mathrm{H}}$ and $\mathrm{N}_{\mathrm{H}} \mathrm{P}_{\mathrm{L}}$, with depletion of only 1 nutrient, the non-limiting nutrient remained constant at much higher levels; at $\mathrm{N}_{\mathrm{L}} \mathrm{P}_{\mathrm{H}}$ the [P] $>10 \mu \mathrm{M}$ (e.g. Fig. 1B) and at $\mathrm{N}_{\mathrm{H}} \mathrm{P}_{\mathrm{L}}$ the $[\mathrm{N}]>200 \mu \mathrm{M}$ (e.g. Fig. 1C).

During the exponential growth phase the relationship between the growth rate $(\mu)$ and salinity could be described with a quadratic function (Fig. 2; salinity: $F_{1,17}=10.63, \mathrm{p}=0.005$, salinity $\left.{ }^{2}: F_{1,17}=12.90, \mathrm{p}=0.002\right)$. Optimal growth was determined at $26 \mathrm{psu}\left(0.43 \mathrm{~d}^{-1}\right)$, which agreed well with the regression model with a calculated optimum at $23.6 \mathrm{psu}$. Nutrient treatments did not differ from each other $\left(F_{3,14}=1.054, \mathrm{p}=0.400\right)$. In other words, at each applied salinity the growth rate of Fibrocapsa japonica cells in exponential phase did not vary for the applied nutrient treatments. Consequently, in all treatments, F. japonica cells had an exponential growth phase (Figs. 1A \& 2), even when at low $\mathrm{P}$ treatments the nutrients were already depleted in $\mathrm{P}$ for at least $2 \mathrm{~d}$ (Fig. 1B). Obviously, cells in these cultures were using $\mathrm{P}$ from storage pools in their cells.

\section{Cell quota for $\mathbf{N}$ and $\mathbf{P}$}

Since similar trends (Fig. 1) for nutrient depletions at different salinities were observed, we calculated the cellular $\mathrm{N}$ and $\mathrm{P}$ quota $(q \mathrm{~N}$ and $q \mathrm{P})$ at $t_{1}$, when

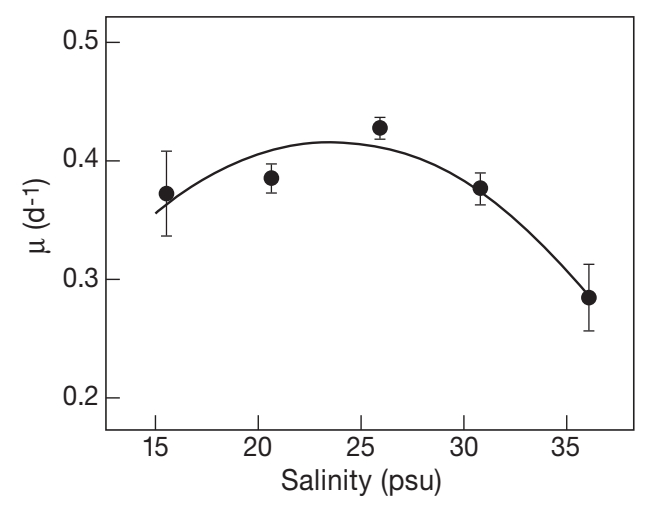

Fig. 2. Relationship between growth rate $\left(\mu, \mathrm{d}^{-1}\right)$ and salinity (model outcome: $\mu=-2.34 \times 10^{-2}+1.96 \times 10^{-2}$ salinity $-4.14 \times$ $10^{-4}$ salinity $^{2}$, with salinity in psu. Averaged values of 4 nutrient treatments with standard errors are shown 
cells were in the exponential phase (for all treatments before depletion occurred), and at $t_{2}$ in the stationary phase at Day 14, when the depleted cells had used their internal P storage (Fig. 3). At time $t_{1}$ (remember, no differences in $\mu$ between nutrient treatments), there were no differences in $q \mathrm{~N}$ or $q \mathrm{P}$ either between the treatments or between salinities; $q N t_{1}$ was $15.3 \pm$ $1.4 \mathrm{pmol} \mathrm{cell}^{-1}$ and $q \mathrm{P} t_{1}$ was $1.25 \pm 0.06 \mathrm{pmol} \mathrm{cell}^{-1}$. In comparison with cell quota at times $t_{1}$ and $t_{2}$ with no $\mathrm{N}$ or $\mathrm{P}$ depletion the cell quota for low $\mathrm{N}$ and low $\mathrm{P}$ treatments $\left(\mathrm{N}_{\mathrm{L}} \mathrm{P}_{\mathrm{L}}\right.$ for both nutrients; $\mathrm{N}_{\mathrm{L}} \mathrm{P}_{\mathrm{H}}$ for $\mathrm{N}_{i} \mathrm{~N}_{\mathrm{H}} \mathrm{P}_{\mathrm{L}}$ for $\mathrm{P}$ ) at time $t_{2}$ showed significant differences. Therefore, at these conditions the nutrients $\mathrm{N}$ or $\mathrm{P}$ were limited and $q \mathrm{Nt}_{2}$ was $7.1 \pm 0.7 \mathrm{pmol} \mathrm{cell}^{-1}$ and $q \mathrm{P} t_{2}$ was $0.29 \pm 0.05$ pmol cell $^{-1}$; both so-called minimum cell quota are denoted as $q_{0} \mathrm{~N}$ and $q_{0} \mathrm{P}$. The optimum N:P ratio for Fibrocapsa japonica, determined as the ratio of minimum cell quotas $q_{0} \mathrm{~N}: q_{0} \mathrm{P}$ (Oh \& Rhee 1991), was 24.5. At $t_{2}$, cultures with the treatment $\mathrm{N}_{\mathrm{L}} \mathrm{P}_{\mathrm{L}}$ had an $\mathrm{N}$ :P ratio of 31 ; apparently these cultures became $P$ limited first. The maximum storage capacity under nutrient-sufficient conditions ( $\mathrm{N}: \mathrm{P}$ ratio 12.3 ) was 2.2 times higher for $\mathrm{N}$ and 4.3 times higher for $\mathrm{P}$ than at the optimum N:P ratio of 24.5 . For the $\mathrm{N}_{\mathrm{H}} \mathrm{P}_{\mathrm{H}}$ treatment there was no difference in cell quota at $t_{1}$ and $t_{2}$, indicating that neither N nor P was limited at Day 14 for this treatment.

\section{Cell behaviour}

For the 4 nutrient treatments, changes in cell behaviour were observed, which depended on the growth phase and nutrients, not on salinity. We observed 2 distinct changes in cell behaviour: impaired motility and aggregation of Fibrocapsa japonica cells (Fig. 3). Nonmotile $F$. japonica cells and cell aggregates at the bottom of the flask were observed in the stationary phase at $\mathrm{P}$ limitation $\left(\mathrm{N}_{\mathrm{L}} \mathrm{P}_{\mathrm{L}}\right.$ and $\mathrm{N}_{\mathrm{H}} \mathrm{P}_{\mathrm{L}}$. In the $\mathrm{N}_{\mathrm{H}} \mathrm{P}_{\mathrm{H}}$ treatment, cells formed aggregates at the surface of the culture in the stationary phase. Only in cultures under $\mathrm{N}$ limitation (only $\mathrm{N}_{\mathrm{L}} \mathrm{P}_{\mathrm{H}}$ ) did cells not aggregate in the stationary phase, but non-motile cells were observed.

\section{Toxin analysis}

For toxicity analysis, at each salinity the samples of the incubations at $\mathrm{N}_{\mathrm{L}} \mathrm{P}_{\mathrm{L}}, \mathrm{N}_{\mathrm{L}} \mathrm{P}_{\mathrm{H}}$ and $\mathrm{N}_{\mathrm{H}} \mathrm{P}_{\mathrm{L}}$ at $t_{2}$ were chosen to make sure that cells were either $\mathrm{N}$ or $\mathrm{P}$ limited and the cell densities were in the same range. The filters of the fourth treatment $\left(\mathrm{N}_{\mathrm{H}} \mathrm{P}_{\mathrm{H}}\right)$ were selected for cells in exponential growth phase not suffering from nutrient limitation. From the dilution series for each treatment (fitted with a sigmoidal curve, $\mathrm{r}^{2}>0.99$ ) the
$\mathrm{EC}_{50}$ was calculated as the concentration of Fibrocapsa japonica (cells ml ${ }^{-1}$ ) necessary for $50 \%$ lysis of the erythrocytes. The relationship between this $\mathrm{EC}_{50}$ and salinity could be described with a quadratic function (Fig. 4 ; salinity: $F_{1,16}=15.68, \mathrm{p}=0.001$, salinity ${ }^{2}: F_{1,16}=$ 12.06, $\mathrm{p}=0.003$ ). Among all the nutrient conditions examined there were significant differences in $\mathrm{EC}_{50}$ data sets $\left(F_{3,14}=11.06, \mathrm{p}=0.001\right)$. This was due to the difference between treatment $\mathrm{N}_{\mathrm{L}} \mathrm{P}_{\mathrm{H}}$ (N limited) and the others (non-N limited), since values from the non-N limited treatments were not different from each other $\left(F_{2,10}=0.181, \mathrm{p}=0.837\right)$. In the final model, the $\mathrm{EC}_{50}$ values for the $\mathrm{N}_{\mathrm{L}} \mathrm{P}_{\mathrm{H}}$ cultures were higher than for the other cultures $\left(F_{1,16}=36.95, \mathrm{p}<0.001\right)$, indicating less haemolytic activity when cells are $\mathrm{N}$ limited. The effect of the growth phase in the 2 sets of data (exponential growth phase vs cells in stationary growth phase) did not differ (i.e. there were no interactions $F_{2,14}=4.73$, $\mathrm{p}=0.112$ ). The highest haemolytic activity was found

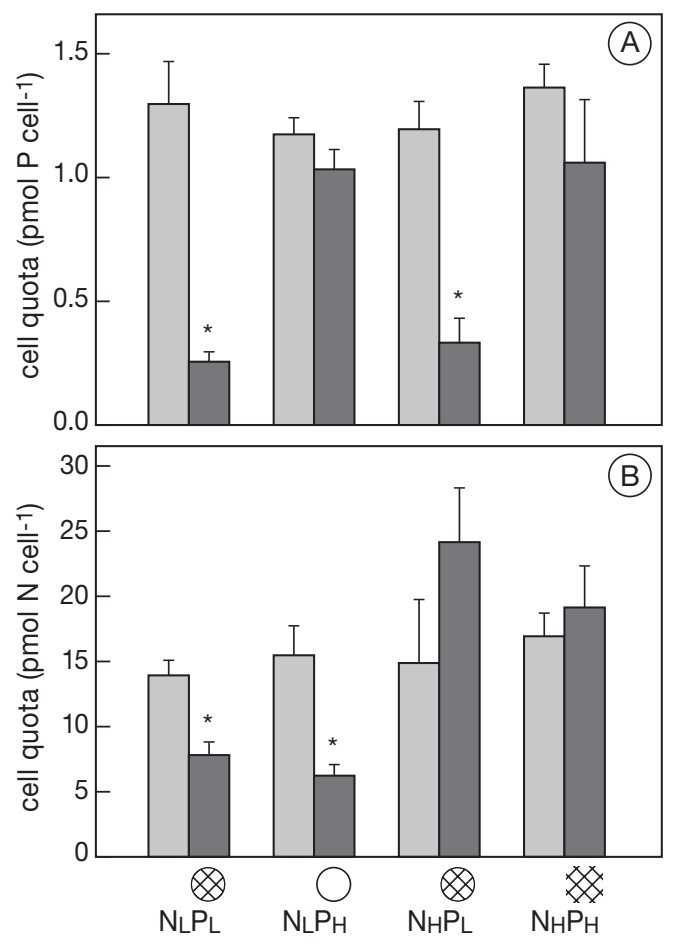

Fig. 3. Fibrocapsa japonica. Cell quota for (A) P and (B) $\mathrm{N}$ of cell for each nutrient treatment at $t_{1}$, exponential phase (lightgrey bars), and $t_{2}$, stationary phase (dark-grey bars). Average values of 5 salinity treatments with their standard errors were used, because there were no significant differences between the salinities. ${ }^{*}$ : differences between $t_{1}$ and $t_{2}$ are significant at the 0.05 level. Changes in cell behaviour at $t_{2}$ are indicated as: circle $=$ non-motile cells in culture observed at the bottom of the flask; crosshatched = cell aggregation in culture; crosshatched circle $=$ non-motile cells and cell aggregates at the bottom of the flask 


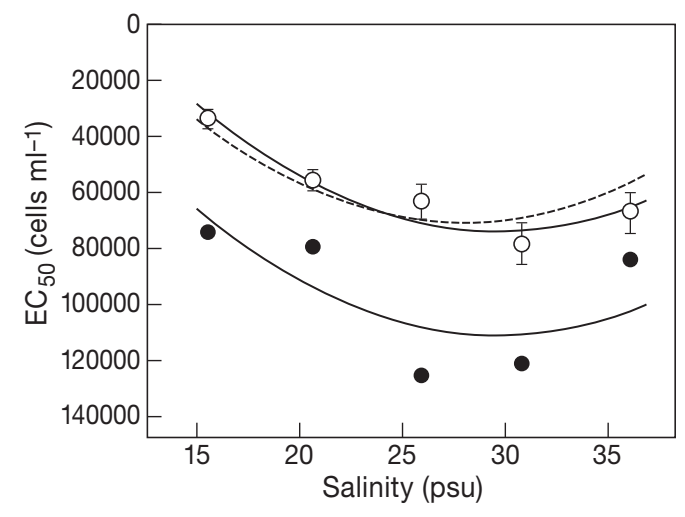

Fig. 4. Relationship between the Fibrocapsa japonica cell density (cells $\mathrm{ml}^{-1}$ ) causing $50 \%$ haemolysis $\left(\mathrm{EC}_{50}\right.$ ) and salinity $(\bullet) \mathrm{N}$-limited cells measured at the beginning of the stationary phase of growth (model outcome: $\mathrm{EC}_{50}=3.66 \times 10^{4}$ +6216 salinity - 105 salinity $^{2}$ ). (0) Average values of 3 nonN-limited treatments with standard error (model outcome: $\mathrm{EC}_{50}=-5.5 \times 10^{4}+6216$ salinity -105 salinity $^{2}$ ). Dotted line: relationship between the $\mathrm{EC}_{50}\left(\right.$ cells $\mathrm{ml}^{-1}$ ) for non-N-limited treatments corrected on basis of mean equal cell volume (model outcome: $\mathrm{EC}_{50}=-5.1 \times 10^{4}+6177$ salinity -111 salinity $^{2}$ ), with salinity in psu

at 16 psu (mean $\mathrm{EC}_{50}=1.7 \times 10^{4} \mathrm{cells} \mathrm{m}^{-1}$ ) and was at least 2.3 times more haemolytic than at 30 psu.

No haemolytic activity was observed for PbTx 2 and no brevetoxins were found in the samples.

\section{DISCUSSION}

For the first time, cell quotas have been determined for nutrient-limited $\left(q_{0} \mathrm{~N}\right.$ and $\left.q_{0} \mathrm{P}\right)$ and non-limited $(q \mathrm{~N}$ and $q \mathrm{P}$ ) cells of Fibrocapsa japonica. In comparison with the minimum cell quota for $\mathrm{N}$ and $\mathrm{P}$ of Emiliania huxleyi and various HAB species, the minimum cell quotas of $F$. japonica were usually higher; they were similar to the values for the dinoflagellate Alexandrium catenella, and lower than those of the raphidophyte Chattonella antiqua (Table 2). The cell volumes of $A$. catenella and $C$. antiqua, however, are 3 and 8 times larger than we have determined for F. japonica. Other raphidophyte species (Chattonella verruculosa and Heterosigma akashiwo) have half the cell volume of $F$. japonica combined with much lower minimum cell quotas (Watanabe et al. 1982, Yamaguchi et al. 2001). This indicates that (under similar nutrient conditions) these raphidophytes are expected to grow to higher cell densities than F. japonica. In proportion to its cell volume, $F$. japonica needs substantially more $\mathrm{N}$ and P compared to other species (Nakamura 1985, Matsuda et al. 1999). When minimum cell quotas are expressed per cell volume unit, the coccolithophorid $E$. huxleyi has, so far, the same high nutrient requirements ( $\mathrm{N}$ and $\mathrm{P}$ in pmol $\mu \mathrm{m}^{-3}$ ). In addition to F. japonica, E. huxleyi and the HAB species $C$. verruculosa and A. catenella also had an optimum N:P ratio higher than the Redfield ratio of 16 (Riegman et al. 1998, Matsuda et al. 1999, Yamaguchi et al. 2001). A high optimum nutrient ratio (the ratio at which transition from one nutrient limitation to another occurs; Rhee \& Gotham 1980 ) indicates that at Redfield ratio these HAB species are $\mathrm{N}$ limited. When sufficient nutrients were available, $F$. japonica cells appeared to have a higher maximum storage capacity for P than for N. F. japonica cells entering stationary phase with sufficient nutrients $\left(\mathrm{N}_{\mathrm{H}} \mathrm{P}_{\mathrm{H}}\right.$ treatments) were most likely rate limited by diffusion of $\mathrm{CO}_{2}$.

Our results show that Fibrocapsa japonica is very suitable to grow in eutrophied coastal waters and is able to compete with species with a low optimum $\mathrm{N}: \mathrm{P}$ ratio; F. japonica requires less phosphate. Since 1987 a shift was observed in the nutrient-rich eutrophied

Table 2. Optimum N:P ratios and minimum cell quotas $\left(q_{0} \mathrm{~N}\right.$ and $\left.q_{0} \mathrm{P}\right)$ of a selection of marine harmful algal bloom species and Emiliania huxleyi (derived from Yamaguchi et al. 2001). The volume of the cell is from the accompanying reference or calculated using the morphological parameters of the species (Fukuyo et al. 1990) and the species-specific formulas from Hillebrand et al. (1999)

\begin{tabular}{|c|c|c|c|c|c|}
\hline \multirow[t]{2}{*}{ Species } & \multirow{2}{*}{$\begin{array}{l}\text { Optimum } \\
\text { N:P ratio }\end{array}$} & \multicolumn{2}{|c|}{ Minimum cell quota } & \multirow{2}{*}{$\begin{array}{l}\text { Cell volume } \\
\qquad\left(\mu \mathrm{m}^{3}\right)\end{array}$} & \multirow[t]{2}{*}{ Source } \\
\hline & & $q_{0} \mathrm{~N}\left(\mathrm{fmol} \mathrm{cell}{ }^{-1}\right)$ & $q_{0} \mathrm{P}\left(\mathrm{fmol} \mathrm{cell}{ }^{-1}\right)$ & & \\
\hline Heterocapsa circularisquama & 12.4 & 1100 & 89 & 2000 & Yamaguchi et al. (2001) \\
\hline Gymnodinium mikimotoi & 12.5 & 3130 & 250 & $6000^{\mathrm{b}}$ & Yamaguchi \& Itakura (1999) \\
\hline Chattonella antiqua & 12.6 & 7800 & 620 & $24000^{\mathrm{c}}$ & Nakamura (1985) \\
\hline Heterosigma akashiwo & 15.2 & 1440 & 95 & 2100 & Watanabe et al. (1982) \\
\hline Emiliania huxleyi & 17.9 & 71.4 & 4 & 50 & Riegman et al. (1998) \\
\hline Alexandrium catenella & 22.8 & 7300 & 320 & $11100^{\mathrm{b}}$ & Matsuda et al. (1999) \\
\hline Fibrocapsa japonica & 24.5 & 7100 & 290 & 4400 & Present study \\
\hline Chattonella verruculosa & 33.6 & 84 & 2.5 & $1700^{\mathrm{b}}$ & Yamaguchi et al. (2001) \\
\hline \multicolumn{6}{|c|}{$\begin{array}{l}\text { a Given cell volume, irrespective of environmental conditions } \\
{ }^{b} \text { Calculated from cell dimensions } \\
{ }^{c} \text { Nakamura \& Watanabe (1983) }\end{array}$} \\
\hline
\end{tabular}


Dutch coastal waters towards a phosphorus-controlled system due to reduction of phosphate discharge (Peeters et al. 1999, Philippart et al. 2000). Such eutrophied phosphorus-controlled systems may favour large phytoplankton species with relatively high optimum $\mathrm{N}: \mathrm{P}$ ratios (>Redfield ratio), such as $F$. japonica. Notably, this species has been observed in Dutch coastal waters since 1991 (Vrieling et al. 1995).

Its relatively large minimum cell quota suggests that Fibrocapsa japonica is not very efficient with nutrients, and therefore probably needs other ecological advantages to enable it to become a dominant species in the natural environment. A good example is the decreased vulnerability to grazers as demonstrated for the raphidophyte Heterosigma akashiwo (Tomas 1980). For this species the dual strategy of grazer avoidance and inhibition of autotrophic competitors partially compensates for its inferior $\mathrm{N}$ uptake capability (French \& Smayda 1995). Motility of F. japonica appears to be quite an effective defence mechanism against grazers such as pallium-feeding dinoflagellates (Tillmann \& Reckermann 2002). Our F. japonica cells, however, showed less motility when growth entered the stationary phase and either $\mathrm{N}$ or $\mathrm{P}$ became limiting. We conclude that under nutrient limitation, cell motility of $F$. japonica does not seem to be the strategy for grazer avoidance.

When entering stationary phase, cells under $\mathrm{P}$ and/or C limitation produce sticky aggregates that could play a role in their palatability. Extrusion of mucocysts by Fibrocapsa japonica acts mechanically as a grazer deterrent (Tillmann \& Reckermann 2002). Cells of their strain tore up the pallia of the dinoflagellate Oblea rotunda (Tillmann \& Reckermann 2002) and cells of a Japanese strain induced stress behaviour in Artemia salina (Rhodes et al. 1993, Cho et al. 1999).

Another explanation for the ability of Fibrocapsa japonica to produce blooms is toxicity of the cells. Fish kills related to $F$. japonica blooms have been explained by the production of brevetoxins, ROS, haemolytic compounds or mucocyst threads (Khan et al. 1996, Oda et al. 1997, Bridgers et al. 2004, Fu et al. 2004a,b, de Boer et al. 2004b). From some raphidophyte species (Heterosigma akashiwo, Chattonella antiqua and Chattonella marina), it is known that salinity affects the production of brevetoxins (Haque \& Onoue $2002 \mathrm{a}, \mathrm{b})$. The highest brevetoxin concentration and ichthyotoxicity was found at low salinity (20 psu) in the late exponential phase for $H$. akashiwo (Haque \& Onoue 2002a). For C. marina and C. antiqua, toxicity dropped drastically when salinity exceeded 30 psu (Haque \& Onoue 2002b). For some F. japonica strains, brevetoxins were found (Khan et al. 1996, Bridgers et al. 2004). Using the sensitive ELISA assay, however, we could not demonstrate the presence of brevetoxins in our strain.
Our Fibrocapsa japonica is capable of producing haemolytic compounds, 3 of which have been identified as polyunsaturated fatty acids (PUFAs; Fu et al. $2004 a, b)$. We demonstrated the haemolytic activity of F. japonica cell compounds in all 20 nutrient/salinity treatments (Fig. 4). Between exponential and stationary phase, no significant difference was found in the haemolytic activity of $F$. japonica. Production of these haemolytic compounds could have ecological advantages like inhibitory effects on growth of nutrient competitors (algae, bacteria) and act as grazer deterrent.

Salinity had a significant effect on the maximum growth rates and on the haemolytic activity (Figs. 2 \& $4)$. If the differences in haemolytic activity coupled to salinity are due to osmotic effects, these do not couple with growth rates. To investigate the effect of salinity on cell size we did additional growth experiments (data not shown) that revealed bigger cells with increasing salinity (cell volume $=2908+57.07$ salinity, $\left.\mathrm{n}=7 ; \mathrm{r}^{2}=0.973 ; \mathrm{p}<1 \times 10^{-4}\right)$. This finding has consequences for the interpretation of toxicity expressed on a per cell basis. Assuming a constant haemolytic activity per cell volume unit an approximation on the basis of equal biovolume for each activity was made for conditions without $\mathrm{N}$ limitation (Fig. 4). After correction for cell volume there is still an effect of salinity on the $\mathrm{EC}_{50}$ of Fibrocapsa japonica indicating a physiological basis for the observed differences related to salinity.

For other algae it is shown that nutrient limitation affects cell volume as well (Boyer et al. 1987, Simonsen \& Moestrup 1997, Riegman et al. 1998), although for Alexandrium tamarense an increase in cell volume at $\mathrm{P}$ limitation did not entirely explain the increased toxin production (Boyer et al. 1987, Simonsen \& Moestrup 1997). In our case, a slight decrease in cell volume of Fibrocapsa japonica under $\mathrm{N}$ limited conditions (from $4300 \mu \mathrm{m}^{3}, \varnothing 20.2 \mu \mathrm{m}$, to $2800 \mu \mathrm{m}^{3}, \varnothing 17.5 \mu \mathrm{m}$ at $25 \mathrm{psu}$ ) is enough to explain the significant difference in haemolytic activity observed between $\mathrm{N}$ and non- $\mathrm{N}$ limited conditions. Therefore, volume changes rather than physiological adaptation seem to be the reason for the observed differences.

The effects of different environmental conditions on the production of toxins can vary substantially and are likely to be species specific (Johansson \& Granéli 1999b). Here Fibrocapsa japonica cells always produced haemolytic compounds in contrast to the nutrient-limiting conditions that were needed for prymnesiophyte toxicity (Johansson \& Granéli 1999a,b). For Alexandrium tamarense, both the haemolytic activity and the production of PSP toxins were highest in the exponential growth phase (Simonsen et al. 1995). Salinity rather than growth phase had a significant effect on the haemolytic activity of F. japonica. 
To compare our results with other haemolytic species, studies were selected where the $\mathrm{EC}_{50}$ of saponin as reference compound was also determined (Table 3). Except for Chrysochromulina simplex all species are $\mathrm{HAB}$ species. Note that increasing $\mathrm{EC}_{50}$ values relate to decreasing haemolytic activities. The highest haemolytic activity of Fibrocapsa japonica was found at low salinity (16 psu), which was in the same range as Prymnesium parvum under N- or P-limited conditions (Johansson \& Granéli 1999b). However, if for the $\mathrm{EC}_{50}$ the differences in cell volume are taken into account, the haemolytic activity of $P$. parvum on a per volume basis is about 14 times higher than F. japonica and equal to Alexandrium tamarense, which had a high haemolytic activity per cell (Eschbach et al. 2001). Cell volume based haemolytic activity of $F$. japonica is about 8 times higher than that of Chrysochromulina polylepis (Simonsen \& Moestrup 1997). The haemolytic activity of phytoplankton cell extracts does not always translate into toxicity for aquatic organisms (Yasumoto et al. 1987, Simonsen \& Moestrup 1997). This toxicity is also dependent on the amount and type of haemolytic compounds, which differ between species (Yasumoto et al. 1987, Simonsen \& Moestrup 1997) and environmental conditions (Johansson \& Granéli 1999b).

We expect that most of the observed haemolytic activity of Fibrocapsa japonica was due to the haemolytic PUFAs; 6, 9,12,15-octadecatetraenoic acid (OTA or stearidonic acid; C18:4n3), 5, 8,11,14,17-eicosapentaenoic acid (EPA; C20:5n3) and 5,8,11,14-eicosatetraenoic acid (arachidonic acid, AA; C20:4n6), that were recently identified in this strain (Fu et al. 2004a). These may be involved in a lipoxycascade starting with the hydrolysis of lipids and rapid formation of PUFA when a cell is disrupted (Jüttner 2001). Mass aggregation of $F$. japonica cells could indicate such a cell damage, causing leakage of allelopathic, toxic

Table 3. An overview of the haemolytic studies on microalgae compared to the results obtained for our strain of Fibrocapsa japonica. For comparison, microalgae $\mathrm{EC}_{50}$ values (cell density [cells $\mathrm{ml}^{-1}$ ] causing $50 \%$ haemolysis) were corrected for differences in experimental conditions using the reported assay-specific saponin $\mathrm{EC}_{50}$ values and normalising for the $\mathrm{EC}_{50}$ for saponin of this experiment. The volume of the cell is from Simonsen \& Moestrup (1997) or calculated using the morphological parameters of the species (Fukuyo et al. 1990) and the species specific formulas from Hillebrand et al. (1999)

\begin{tabular}{|c|c|c|c|c|c|}
\hline Species & $\begin{array}{l}\text { Nutrient } \\
\text { conditions }\end{array}$ & $\begin{array}{c}\mathrm{EC}_{50} \\
\text { saponin } \\
\left(\mathrm{mg} \mathrm{ml}^{-1}\right)\end{array}$ & $\begin{array}{c}\mathrm{EC}_{50} \\
\text { microalgae } \\
\left(10^{4} \text { cells ml }{ }^{-1}\right)\end{array}$ & $\begin{array}{c}\text { Cell } \\
\text { volume } \\
\left(\mu \mathrm{m}^{3}\right)\end{array}$ & Source \\
\hline Fibrocapsa japonica & $\mathrm{N}$ limited & 0.0045 & 6.3 & 4400 & At $26 \mathrm{psu}$; this study \\
\hline Fibrocapsa japonica & Non-N limited & 0.0045 & 3.2 & 4400 & At $26 \mathrm{psu}$; this study \\
\hline Fibrocapsa japonica & Non-N limited & 0.0045 & 1.7 & 3800 & At 16 psu; this study \\
\hline Alexandrium tamarense CCMP115 & & 0.0045 & 0.0152 & $18700^{\mathrm{b}}$ & Eschbach et al. (2001) \\
\hline Chrysochromulina polylepis K-0259 & P limited & 0.1430 & 170.3 & 270 & Simonsen \& Moestrup (1997) \\
\hline Chrysochromulina polylepis K-0259 & P limited & 0.1430 & 154.8 & 270 & Simonsen \& Moestrup (1997) \\
\hline Chrysochromulina polylepis K-0259 & P limited & 0.1430 & 155.7 & 270 & Simonsen \& Moestrup (1997) \\
\hline Chrysochromulina polylepis K-0259 & P limited & 0.1430 & 116.2 & 270 & Simonsen \& Moestrup (1997) \\
\hline Chrysochromulina simplex K-0272 & P limited & 0.1430 & 1575.6 & 60 & Simonsen \& Moestrup (1997) \\
\hline Prymnesium parvum K-0081 & P limited & 0.1430 & 0.6 & 280 & Simonsen \& Moestrup (1997) \\
\hline Prymnesium parvum K-0081 & (Day 2; log phase) & 0.1430 & 18.8 & 280 & Simonsen \& Moestrup (1997) \\
\hline Prymnesium parvum K-0081 & (Day 6; log phase) & 0.1430 & 11.0 & 280 & Simonsen \& Moestrup (1997) \\
\hline Prymnesium parvum K-0081 & (Day 10; late log phase) & 0.1430 & 7.2 & 280 & Simonsen \& Moestrup (1997) \\
\hline Prymnesium parvum K-0081 & (Day 16 ; stat phase) & 0.1430 & 17.0 & 280 & Simonsen \& Moestrup (1997) \\
\hline Prymnesium parvum K-0081 & (Day 21; stat phase) & 0.1430 & 24.7 & 280 & Simonsen \& Moestrup (1997) \\
\hline Prymnesium parvum & $\mathrm{N}$ limited & 0.2270 & 1.0 & 280 & Johansson \& Granéli (1999b) \\
\hline Prymnesium parvum & P limited & 0.2270 & 1.2 & 280 & Johansson \& Granéli (1999b) \\
\hline Prymnesium parvum & Not limited & 0.2270 & 6.8 & 280 & Johansson \& Granéli (1999b) \\
\hline Prymnesium parvum RL10 & & 0.0045 & 1.0 & 280 & Eschbach et al. (2001) \\
\hline Prymnesium parvum KAC $39^{\mathrm{c}}$ & $0 \%$ DOM $100 \% \mathrm{NO}_{3}$ & 0.1610 & 0.4 & 280 & Stolte et al. (2002) \\
\hline Prymnesium parvum KAC $39^{\mathrm{c}}$ & $25 \%$ DOM $75 \% \mathrm{NO}_{3}$ & 0.1610 & 0.3 & 280 & Stolte et al. (2002) \\
\hline Prymnesium parvum KAC $39^{\mathrm{c}}$ & $50 \%$ DOM $50 \% \mathrm{NO}_{3}$ & 0.1610 & 0.3 & 280 & Stolte et al. (2002) \\
\hline Prymnesium parvum KAC $39^{c}$ & Cell-free filtrate, $t=0$ & 0.1610 & 1.0 & 280 & Fistarol et al. (2003) \\
\hline Prymnesium parvum KAC $39^{c}$ & Cell-free filtrate, $t=48 \mathrm{~h}$ & 0.1610 & No haemolysis & 280 & Fistarol et al. (2003) \\
\hline \multicolumn{6}{|c|}{$\begin{array}{l}{ }^{\mathrm{a}} \text { Given cell volume, irrespective of environmental conditions } \\
\text { b } \\
{ }^{\mathrm{c}} \text { Palculated from cell dimensions } \\
{ }^{\mathrm{c}} \text { Prymesium parvum f. patelliferum KAC } 39\end{array}$} \\
\hline
\end{tabular}


and/or haemolytic substances into the environment. Such leakage of haemolytic compounds into the medium was demonstrated when cells of Prymnesium parvum shifted from exponential growth phase into stationary growth phase (Simonsen \& Moestrup 1997).

In some studies, EPA was shown to provide a defensive role against grazers (zooplankton; Jüttner 2001), allelopathic protection towards phytoplankton species (Arzul et al. 1998) and a toxic effect for fish (Marshall et al. 2003). Enhanced ichthyotoxicity of EPA in the presence of superoxide seems to account for the high potential of Chattonella marina to kill fish (Marshall et al. 2003). It is possible that the same type of mechanism is involved in Fibrocapsa japonica ichthyotoxicity, where haemolytic compound production is combined with the generation of ROS (Oda et al. 1997).

Acknowledgements. We are grateful for the help of the following colleagues: M. Fu and G. Liebezeit, Terramare Research Centre Wilhelmshaven, Germany (co-operation); A. Weidner-Lenzi and J. Naar, Center for Marine Science, UNCW, Wilmington, USA (brevetoxin analysis); G. van Dijk, Animal Physiology, University of Groningen (providing fresh rat blood) and J. H. Dillingh, University of Groningen $\left(\mathrm{EC}_{50}\right.$ estimations). The authors thank W. J. Wolff, W. W. C. Gieskes, G. C. Cadée and 2 anonymous reviewers for the valuable comments on the manuscript. M.K.deB. was supported by the Dutch National Science Foundation; Earth and Life Science (NWO-ALW) project 809.34.004 and M.R.T. and M.v.R. were supported by NWO Priority Programme theme 3 'Sustainable use and conservation of marine living resources'.

\section{LITERATURE CITED}

Arzul G, Bodennec G, Gentien P, Bornens P, Crassous MP (1998) The effect of dissolved oxygen on the haemolytic property of Gymnodinium ichthyotoxins. In: Reguera B, Blanco J, Fernández ML, Wyatt T (eds) Harmful algae. Xunta de Galicia and Intergovernmental Oceanographic Commission of UNESCO, Vigo, p 611-614

Bourdelais AJ, Tomas CR, Naar J, Kubanek J, Baden DG (2002) New fish-killing alga in coastal Delaware produces neurotoxins. Environ Health Perspect 110:465-470

Boyer GL, Sullivan JJ, Andersen RJ, Harrison PJ, Taylor FJR (1987) Effects of nutrient limitation on toxin production and composition in the marine dinoflagellate Protogonyaulax tamarensis. Mar Biol 96:123-128

Bridgers A, McConnel E, Naar J, Weidner A, Tomas L, Tomas CR (2004) Comparison of regional clones of the genus Chattonella and Fibrocapsa for growth characteristics and potential toxin production. In: Steidinger KA, Landsberg JH, Tomas CR, Vargo GA (eds) Harmful algae 2002. Florida Fish and Wildlife Conservation Commission and Intergovernmental Oceanographic Commission of UNESCO (in press)

Cadée GC, Hegeman JJ (1993) Persisting high levels of primary production at declining phosphate concentrations in the Dutch coastal area. Neth J Sea Res 31:147-152

Cadée GC, Hegeman JJ (2002) Phytoplankton in the Marsdiep at the end of the 20th century; 30 years monitoring biomass, primary production, and Phaeocystis blooms.
J Sea Res 48:97-110

Carrasquero-Verde JR (1999) Role of associated bacteria in Heterosigma carterae toxicity to salmonids. Aquat Toxicol 45:19-34

Cho ES, Rhodes LL, Kim HG (1999) The comparison of two strains of Fibrocapsa japonica (Raphidophyceae) in New Zealand and Japan. J Fish Sci Technol 2:58-65

Colijn F, Cadée GC (2003) Is phytoplankton growth in the Wadden Sea light or nitrogen limited? J Sea Res 49:83-93

Crawley MJ (1993) GLIM for ecologists. Blackwell Scientific Publications, Oxford

de Boer MK, Van Rijssel M, Vrieling EG (2004a) Morphology of Fibrocapsa japonica cysts formed under laboratory conditions. In: Steidinger KA, Landsberg $\mathrm{JH}_{\text {, Tomas }} \mathrm{CR}_{\text {, }}$ Vargo GA (eds) Harmful algae 2002. Florida Fish and Wildlife Conservation Commission and Intergovernmental Oceanographic Commission of UNESCO (in press)

de Boer MK, Koolmees EM, Vrieling EG, Breeman AM, Van Rijssel M (2004b) Temperature responses of three Fibrocapsa japonica strains (Raphidophyceae) from different climate regions. J Plankton Res (in press)

Eschbach E, Scharsack JP, John U, Medlin LK (2001) Improved erythrocyte lysis assay in microtitre plates for sensitive detection and efficient measurement of haemolytic compounds from ichthyotoxic algae. J Appl Toxicol 21:513-519

European Commission (2003) The EU-US scientific initiative on Harmful Algal Blooms. Workshop Report, EUR 20578, Brussels

Fistarol GO, Legrand C, Granéli E (2003) Allelopathic effect of Prymnesium parvum on a natural plankton community. Mar Ecol Prog Ser 255:115-125

French DP, Smayda TJ (1995) Temperature regulated responses of nitrogen limited Heterosigma akashiwo, with relevance to its blooms. In: Lassus P, Arzul G, Erard E, Gentien P, Marcaillou C (eds) Harmful marine algal blooms. Lavoisier, Paris, p 585-590

Fu M, Koulman A, Van Rijssel M, Lützen A, de Boer MK, Tyl MR, Liebezeit G (2004a) Chemical characterisation of three haemolytic compounds from the microalgal species Fibrocapsa japonica (Raphidophyceae). Toxicon 43: 355-363

Fu M, Van Rijssel M, Liebezeit G (2004b) Hemolytic compounds from Fibrocapsa japonica (Raphidophyceae). In: Steidinger KA, Landsberg JH, Tomas CR, Vargo GA (eds) Harmful algae 2002. Florida Fish and Wildlife Conservation Commission and Intergovernmental Oceanographic Commission of UNESCO (in press)

Fukuyo Y, Takano H, Chihara M, Matsuoka K (1990) Red tide organisms in Japan-an illustrated taxonomic guide. Uchida Rokakuho, Tokyo

Granéli E, Johansson N, Panosso R (1998) Cellular toxin contents in relation to nutrient conditions for different groups of phycotoxins. In: Reguera B, Blanco J, Fernandez ML, Wyatt $\mathrm{T}$ (eds) Harmful algae. Xunta de Galicia and Intergovernmental Oceanographic Commission of UNESCO, Vigo, p 321-324

Guillard, RRL (1975) Culture of phytoplankton for feeding marine invertebrates. In: Smith WL, Chanley MH (eds) Culture of marine invertebrate animals. Plenum Press, New York, p 108-132

Hallegraeff GM, Anderson DM, Cembella AD (2003) Manual on harmful marine microalgae. UNESCO Publishing, Paris

Haque SM, Onoue Y (2002a) Effects of salinity on growth and toxin production of a noxious phytoflagellate, Heterosigma akashiwo (Raphidophyceae). Bot Mar 45:356-363

Haque SM, Onoue Y (2002b) Variation in toxin compositions 
of two harmful raphidophytes, Chattonella antiqua and Chattonella marina, at different salinities. Environ Toxicol 17:113-118

Harrison PJ (1988) Determining phosphate uptake rates of phytoplankton. In: Lobban CS, Chapman DJ, Kremer BP (eds) Experimental phycology; a laboratory manual. Cambridge University Press, Cambridge, p 186-195

Hillebrand H, Dürselen CD, Kirschtel D, Pollinger U, Zohary $\mathrm{T}$ (1999) Biovolume calculation for pelagic and benthic microalgae. J Phycol 35:403-424

Ishimatsu A, Oda T, Yoshida M, Ozaki M (1996) Oxygen radicals are probably involved in the mortality of yellowtail by Chattonella marina. Fish Sci 62:836-837

Iwasaki H (1971) Studies on the red tide flagellates. VI. On Eutreptiella sp. and Exuviaella sp. appeared in BingoNada, the Seto Inland Sea, in 1970. J Oceanogr Soc Jpn 27:152-157

Johansson N, Granéli E (1999a) Cell density, chemical compostition and toxicity of Chrysochromulina polylepis (Haptophyta) in relation to different N:P ratios. Mar Biol 135:209-217

Johansson N, Granéli E (1999b) Influence of different nutrient conditions on cell density, chemical composition and toxicity of Prymnesium parvum (Haptophyta) in semi-continuous cultures. J Exp Mar Biol Ecol 239:243-258

Jüttner F (2001) Liberation of 5,8,11,14,17-eicosapentaenoic acid and other polyunsaturated fatty acids from lipids as a grazer defense, reaction in epilythic diatom biofilms. J Phycol 37:744-755

Khan S, Arakawa O, Onoue Y (1996) Neurotoxin production by a chloromonad Fibrocapsa japonica (Raphidophyceae). J World Aquacult Soc 27:254-263

Khan S, Ono K, Haruyama M, Iwashita T, Onoue Y (2001) Environmental factors affecting the neurotoxin production of Chattonella antiqua (Raphidophyceae). In: Hallegraeff GM, Blackburn SI, Bolch CJ, Lewis RJ (eds) Harmful algal blooms 2000. Intergovernmental Oceanographic Commission of UNESCO, Paris, p 308-311

Landsberg JH (2002) The effects of harmful algal blooms on aquatic organisms. Rev Fish Sci 10:113-390

Marshall JA, Hovenden M, Oda T, Hallegraeff GM (2002) Photosynthesis does influence superoxide production in the ichthyotoxic alga Chattonella marina (Raphidophyceae). J Plankton Res 24:1231-1236

Marshall JA, Nichols PD, Hamilton B, Lewis RJ, Hallegraeff GM (2003) Ichthyotoxicity of Chattonella marina (Raphidophyceae) to damselfish (Acanthochromis polycanthus): the synergistic role of reactive oxygen species and free fatty acids. Harmful Algae 2:273-281

Matsuda A, Nishijima T, Fukami K (1999) Effect of nitrogenous and phosphorus nutrients on the growth of toxic dinoflagellate Alexandrium catenella. Nippon Suisan Gakkaishi 65:847-855

Naar J, Bourdelais AJ, Tomas CR, Kubanek J and 5 others (2002) A competitive ELISA to detect brevetoxins from Karenia brevis (formerly Gymnodinium breve) in seawater, shellfish, and mammalian body fluid. Environ Health Perspect 110:179-185

Nakamura Y (1985) Kinetics of N- or P-limited growth and effects of growth conditions on nutrient uptake in Chattonella antiqua. J Oceanogr Soc Jpn 41:381-387

Nakamura Y, Watanabe M (1983) Growth characteristics of Chattonella antiqua. Part 2. Effects of nutrients on growth. J Oceanogr Soc Jpn 39:151-155

Oda T, Nakamura A, Shikayama M, Kawano I, Ishimatsu A, Muramatsu T (1997) Generation of reactive oxygen species by raphidophycean phytoplankton. Biosci Biotechnol
Biochem 61:1658-1662

Officer CB, Ryther JH (1980) The possible importance of silicon in marine eutrophication. Mar Ecol Prog Ser 3: 83-91

Oh HM, Rhee GY (1991) A comparative-study of microalgae isolated from flooded rice paddies-light-limited growth, $\mathrm{C}$-fixation, growth efficiency and relative- $\mathrm{N}$ and relativeP requirement. J Appl Phycol 3:211-220

Okaichi T (1972) Occurrence of red-tides related to neritic water pollution. In: The cause of red-tide in neritic waters. Japanese Association for the Protection of Fisheries Resources, Tokyo, p 58-76

Okaichi T (1989) Red tide problems in the Seto Inland Sea, Japan. In: Okaichi T, Anderson DM, Nemoto T (eds) Red tides, biology, environmental science and toxicology. Elsevier, New York, p 137-142

Ono K, Khan S, Onoue Y (2000) effects of temperature and light intensity on the growth and toxicity of Heterosigma akashiwo (Raphidophyceae). Aquacult Res 31:427-433

Peeters JCH, de Vries I, Haas HA (1999) Eutrophication and productivity in the North Sea. Report RIKZ-99.008, National Institute for Coastal and Marine Management (RIKZ), Middelburg

Philippart CJM, Cadée GC, Van Raaphorst W, Riegman R (2000) Long-term phytoplankton-nutrient interactions in a shallow coastal sea: algal community structure, nutrients budgets, and denitrification potential. Limnol Oceanogr 45:131-144

Radach G, Berg J (1986) Trends in der Konzentrationen der Nährstoffe und des Phytoplanktons in der Helgoländer Bucht (Helgoland Reede Daten). Ber Biol Anst Helgol 2: $1-63$

Rademaker M, Reckermann M, Tillmann U, Tillmann-Mayer A, Colijn F, Zevenboom W, Houpt P (1998) Fibrocapsa japonica and Heterosigma akashiwo: new observations. Harmful Algae News 17:8-10

Rhee GY, Gotham IJ (1980) Optimum N:P ratios and coexistence of planktonic algae. J Phycol 16:486-489

Rhodes LL, Haywood AJ, Ballantine WJ, MacKenzie AL (1993) Algal blooms and climate anomalies in north-east New Zealand, August-December 1992. N Z J Mar Freshw Res 27:419-430

Riegman R, Noordeloos AAM, Cadée GC (1992) Phaeocystis blooms and eutrophication of the continental coastal zones of the North Sea. Mar Biol 112:479-484

Riegman R, Stolte W, Noordeloos AAM (1998) A model system approach to biological climate forcing: the example of Emiliania huxleyi. NIOZ Rep 1998-8, Royal Netherlands Institute for Sea Research, Texel

Ryther JH, Dunstan WM (1971) Nitrogen, phosphorus, and eutrophication in the coastal marine environment. Science 171:1113

Simonsen S, Moestrup Ø (1997) Toxicity tests in eight species of Chrysochromulina (Haptophyta). Can J Bot 75: 129-136

Simonsen S, Møller BL, Larsen J, Ravn H (1995) Haemolytic activity of Alexandrium tamarense cells. In: Lassus $\mathrm{P}$, Arzul G, Erard E, Gentien P, Marcaillou C (eds) Harmful marine algal blooms. Lavoisier, Paris, p 513-518

Smayda TJ (1990) Novel and nuisance phytoplankton blooms in the sea: evidence for a global epidemic. In: Granéli E, Sundström B, Edler L, Anderson DM (eds) Toxic marine phytoplankton. Elsevier Science Publishing, New York, p 29-40

Stolte W, Panosso R, Gisselson LA, Granéli E (2002) Utilization efficiency of nitrogen associated with riverine dissolved organic carbon $(>1 \mathrm{kDa})$ by two toxin-produc- 
ing phytoplankton species. Aquat Microb Ecol 29: 97-105

Tillmann U, Reckermann M (2002) Dinoflagellate grazing on the raphidophyte Fibrocapsa japonica. Aquat Microb Ecol 26:247-257

Tomas CR (1980) Olisthodiscus luteus (Chrysophyceae). V. Its occurrence, abundance and dynamics in Narragansett Bay, Rhode Island. J Phycol 16:157-166

Toriumi S, Takano H (1973) Fibrocapsa, a new genus in Chloromonadophyceae from Atsumi Bay, Japan. Bull Tokai Reg Fish Res Lab 76:25-35

Twiner MJ, Trick CG (2000) Possible physiological mechanisms for production of hydrogen peroxide by the ichthyotoxic flagellate Heterosigma akashiwo. J Plankton Res 22: 1961-1975

Veldhuis MJW, Colijn F, Venekamp LAH (1986) The spring bloom of Phaeocystis pouchetii (Haptophyceae) in Dutch coastal waters. J Sea Res 20:37-48

Vrieling EG, Koeman RPT, Nagasaki K, Ishida Y, Peperzak L,

Editorial responsibility: Edna Granéli,

Kalmar, Sweden
Gieskes WWC, Veenhuis M (1995) Chattonella and Fibrocapsa (Raphidophyceae): first observation of, potentially harmful, red tide organisms in Dutch coastal waters. Neth J Sea Res 33:183-191

Watanabe MM, Nakamura Y, Mori S, Yamochi S (1982) Effect of physico-chemical factors and nutrients on the growth of Heterosigma akashiwo Hada from Osaka Bay. Jpn J Phycol 30:279-288

Yamaguchi M, Itakura S (1999) Nutrition and growth kinetics in nitrogen- or phosphorus-limited cultures of the noxious red tide dinoflagellate Gymnodinium mikimotoi. Fish Sci 65:367-373

Yamaguchi M, Itakura S, Uchida T (2001) Nutrition and growth kinetics in nitrogen- or phosphorus-limited cultures of the 'novel red tide' dinoflagellate Heterocapsa circularisquama (Dinophyceae). Phycologia 40:313-318

Yasumoto T, Seino N, Murakami Y, Murata M (1987) Toxins produced by benthic dinoflagellates. Biol Bull (Woods Hole) 172:128-131

Submitted: May 19, 2004; Accepted: August 23, 2004

Proofs received from author(s): October 21, 2004 